\title{
初心不忘，逐梦前行
}

\author{
高福 $1,2,3$
}

1. 中国科学院微生物研究所, 北京 100101 ;

2. 中国疾病预防控制中心, 北京 102206 ;

3. 中国科学院大学存济医学院, 北京 100049

E-mail: gaof@im.ac.cn

\section{Remaining true to our original aspiration, working hard to press ahead}

\author{
George Fu Gao ${ }^{1,2,3}$ \\ ${ }^{1}$ Institute of Microbiology, Chinese Academy of Sciences, Beijing 100101, China;
${ }^{2}$ Chinese Center for Disease Control and Prevention, Beijing 102206, China;
${ }^{3}$ Savaid Medical School, University of Chinese Academy of Sciences, Beijing 100049, China
E-mail: gaof@im.ac.cn
doi: 10.1360/N972018-01308
}

自 2014 年, 我接过《科学通报》大旗, 面对日益激烈的科技期刊国际化竞争, 我和编委会团队 一直在思索: 如何使中文期刊紧跟中国科学技术快速发展的脚步? 《科学通报》如何提高自身水平, 继续肩负起科学家和办刊人的重托与期望? 在具体实践中, 我们逐渐形成了“科学家交流的平台, 国际科学研究的展台, 向世界展示的窗口, 中文期刊的旗舰”的办刊宗旨. 时光飞逝, 转眼间已经到 了 2019 年, 我带领的第二届编委会团队正式上任已有 1 年. 这支新的队伍既有一起奋斗的老朋友, 也有刚刚加入的新生力量. 在过去的 2018 年里, 新老成员携手向前, 围绕办刊目标, 开展了卓有成 效的工作.

我们始终关注科技发展前沿热点, 为科研工作者搭建交流与展示的平台. 2018 年, 新型多孔材 料、水伏纳米材料与器件、量子宇宙物理重大前沿科学问题解读等热点领域专题(辑)报道了我国科 学研究的最新成果. 庆祝北京化工大学建校 60 周年和纪念国家纳米科学中心成立 15 周年专辑则聚

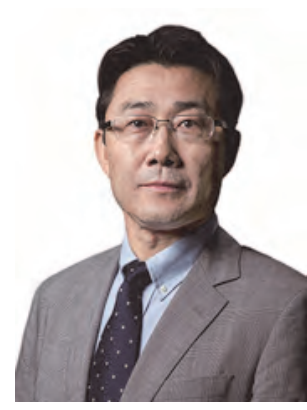

高 福 焦于知名科研院所和高校重点学科的最新进展. 针对大众关心的话题, 从科学的角度进行解读, 组 织了孤独症、抑郁症研究、发展中国的健康城市建设理论与实践、草牧业理论体系与实践等专题(辑). 不忘立足于中国大地, 推 动中华优秀传统文化的传承与发展, 组织出版本草考古-纪念李时珍诞辰 500 周年专题. 为纪念我国重要科学事件, 组织纪念 汶川地震十周年、大洋钻探等专题. 与陈嘉庚科学奖基金会首次合作, 在颁奖之际组织出版专辑, 集中介绍陈嘉庚科学奖和陈 嘉庚青年科学奖的获奖成果, 并阐述各自研究领域的研究现状和未来发展方向. 该专辑的出版充分发挥了多学科综合性科技 期刊的优势，开拓了办刊新思路，也为《科学通报》赢得了更多关注. 新增栏目“亮点述评”和“悦读科学”，在编委会同仁的努 力下已初具规模, 为将其办为特色栏目开了好头; 科学访谈栏目的访谈对象延伸到国际知名科学家, 如对 2003 年物理学诺贝 尔奖得主 Leggett 教授的访谈引起了广泛关注. 这些丰富的文章为实践《科学通报》的办刊初衰和宗旨更进一步.

2018 年, 《科学通报》与香山科学会议的合作也有了新进展. 借助香山科学会议平台, 《科学通报》成功组织召开“强化 中文科技期刊在国家科技创新战略中的作用”香山科学会议, 科学家与期刊人聚集一堂, 围绕办好中文期刊献言献策, 为中文 期刊发声, 再次引发了对中文期刊发展的讨论.

2018 年 11 月 14 日召开的中央全面深化改革委员会第五次会议上, 审议通过了《关于深化改革培育世界一流科技期刊的 意见》, 并强调“科技期刊传承人类文明，荟萃科学发现，引领科技发展，直接体现国家科技竞争力和文化软实力”。中文科技期 刊在推动科技发展、传播中华科技文件中有着不可替代的作用, 承载着一代代科学家和办刊人的厚望. 2019 年, 《科学通报》 跨入第 69 个年头, 我们将牢记办刊宗旨, 不忘初心, 坚守期刊梦, 讲好中国人自己的故事, 期望在 2020 年《科学通报》 70 岁 生日来临之际交上一份完美的答卷.

2019 年新年伊始, 我谨代表编委会和编辑部全体同仁祝愿大家新年好!

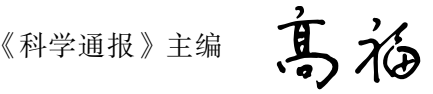

